\title{
EVALUATION OF SUSTAINABLE HOUSING CONCEPT ON KAMPUNG SEPOLOH, AN INFORMAL SETTLEMENT IN SURABAYA, INDONESIA
}

\author{
Anita Dianingrum \& Desy Rahmadaniyati* \\ *) Master student at Department of Architecture, Institut Teknologi Sepuluh \\ Nopember, Surabaya \\ e-mail: anita.dianingrum@yahoo.com
}

\begin{abstract}
Housing is central of sustainable development since it is one of basic social conditions that determine life quality and welfare of people and place. Relationships between housing and sustainable development is addressed by sustainable housing concept, which are considered along four dimensions (environmental, social, cultural and economic). "Kampung Sepoloh" Morokrembangan is one of several informal settlements located in Surabaya Indonesia, which has been doing some efforts to improve its area through environmental approach. This is clear that The Kampung was awarded as "The Best of the Best in advanced category" on Surabaya Green and Clean Competition 2015 held by city government. Based on the achievement, it is necessary for considering the Kampung through the four dimensions of sustainable housing in order to support sustainable development.

The purpose of this study is to seek any potentials related to sustainable housing implementation in "Kampung Sepoloh". This descriptive analytic study examined the case theoretically by observation, interview, and documentation, focusing on the environmental conditions of the kampung. The result shows that "Kampung Sepoloh" has already had some achievements in each dimension. However, there are some aspects that have not run optimally, and be seen as the potentials that need to be developed.
\end{abstract}

Keywords: Kampung Sepoloh, Sustainable Housing, Informal Settlement

\section{INTRODUCTION}

Housing is a basic social conditions that determine the quality of life and welfare of people and places. Since there are many considerations of housing, it is also being important thing to sustainable development. The complex web of inter-relationships between sustainability and housing should be addressed by sustainable housing concept. (UNHABITAT,2012). In addition, "Sustainable housing" is defined as housing with a minimum of negative environmental impacts in terms of climate 
change (greenhouse effect); the quality of air, water, and soil; noise; stench; the stock of non renewable materials; and biodiversity (Priemus,2005).

The issue of affordability is a necessary condition for transformation towards sustainable housing. And yet affordability is not enough, because the socalled affordable homes cannot be considered sustainable if they create negative impacts on the environment or social life. The combination of affordability with other sustainability conditions should be reached. Sustainable affordable housing in this regard may be considered as extension of the adequate shelter- for-all strategy of the Habitat Agenda. Furthermore, the planning and designing concepts of micro scale sustainable housing are organized along the main dimensions of sustainable development (environmental, social, cultural, and economic). UN- Habitat, 2012).

\section{THEORY / RESEARCH METHODS}

The achievement of sustainable housing concept is linked to several required characteristics on each dimensions, those are environmental, social, cultural and economic aspects.

\section{Environmental Dimension}

The environmental sustainability of housing concerned with the impacts of housing on the environment and climate change, as well as the impacts of the environment on housing itself. The following strategies are appropriate for improving environmental sustainability in residences (UN- Habitat, 2012). There are some characteristics that should be concerned on environmental dimension, those are :

1. Considering the whole lifecycle of residential buildings. Considering that all of a house lifecycle, including the planning stage, building design, construction, operation, refurbishment, to the end of its life (UN- Habitat, 2012).

2. Combining the "compact-green"concept to built environments. Integrating compact and green concept by balancing variously dense developments with access to green space, adequate infrastructure and good transport (UN- Habitat ,2012).

3. Environmental performance of residential buildings. The key concerns for the sustainable design of residential buildings lie with their environmental performance, health impact, human comfort, as well as with the provision of appropriate housing management (UN- Habitat, 2012).

4. Integrating housing into sustainable community infrastructure. Considering cogeneration and district heating, distributed power and micro generation, and household waste management and recycling (UN- Habitat, 2012).

5. Implementing the concept of "Healthy Building". Considering the approach of building design, building system, building products, and building maintenance those are safe and not harmful to health. (Bierman,1992). 
6. Sustainable building material and practices. Considering recycling in the construction industry, sustainability of housing construction practices, building materials that are safe for health, and affordable building techniques and materials (UN- Habitat, 2012).

\section{Social and Cultural Dimension}

To ensure the sustainability ini social and cultural dimension, community participation and empowerment should be included. In addition, social infrastructure and facilities should be accessible. There are some characteristics that should be concerned on social and cultural dimension, those are :

1. Creating affordabilty, dignity, and resilience of housing . The economic aspects of affordable housing supply are not enough. The affordable housing is also about dignified shelter - providing people not only with affordable, but also healthy, safe, ecological and resilient place to live (UN-Habitat, 2012).

2. Ensuring social and spatial justice. The sustainable affordable housing improve access to adequate, safe and ecological housing and which involve a degree of the redistribution of wealth and opportunities in favour of the disadvantaged groups, are certainly among important instruments for bridging the social divide and reinforcing social justice (UN-Habitat, 2012).

3. Empowerment, participation and inclusion. Ensuring social and spatial justice and the "right to the city" are achieved and social sustainability is comprehensively addressed necessitates a broadened participation in housing and urban development initiatives and social inclusion and interaction, centering on participation rights, opportunities and responsibilities (UN-Habitat, 2012).

4. Providing acsess to social infrastructure and facilities. Sustainability of residential areas relies on good infrastructure in place (public transport, water, energy sources and public spaces) and accessibility of essential community services (schools, shops, healthcare, but also facilities for families and children) (UN- Habitat, 2012).

5. Residence as coping strategies. Considering that all social groups have higher satisfaction in their life if they feel they are adequately integrated in community structures, social networks. (UN- Habitat, 2012).

6. Adaptable housing for present and future needs. Conceiving that housing has also to be flexible and responsive to various and changing needs of residents (UN- Habitat, 2012).

\section{Economic Dimension}

Affordable housing is a productive asset that has important contributions to national welfare and economic development. Some economic aspects need to pay particularly attention . 
1. Affordability of housing supply. Considering that it is important that in the context of sustainable housing, the traditional measures for improving affordable housing supply are now complemented by the potentials offered by the energy and water efficiency, micro generation, and using ecological local materials and labour (UN- Habitat, 2012).

2. Ensuring balanced housing markets through affordable tenure choices. There are particular problems with macroeconomic policies excessively favouring private housing markets and homeownership. Too much focus on homeownership contributes to market volatilities (UN- Habitat, 2012).

3. Recognising affordable housing building as a source of employment. One of the most important economic functions of housing is its links with employment, especially in the context of poorer areas, where low-cost housing production provides employment for unskilled and skilled labour. (UN- Habitat, 2012).

4. Assisting home-based enterprises. Homebased enterprises (HBEs) phenomenon is very important for generating their income and providing employment. Small-scale homebased enterprises use labour-intensive methods and work within local neighbourhoods to selfemploy their owners and to provide further jobs to the local labour (Tipple, 1993; UN-Habitat, 2006).

5. Mobilising savings and domestic finance. Developing countries have limited financial resources for housing and related infrastructure. It is critical for sustainable housing to define finance solutions (UN-Habitat, 2005).

\section{Method}

This study uses descriptive analytic method, which examined the case theoretically by observation, interviews, and documentation, focusing on the environmental conditions of "Kampung Sepoloh ". The techniques of data analysis include:

1. Doing literature study and understanding the concept of "Sustainable Housing for Sustainable Cities" from UN-Habitat (2012) and the concept of "Healthy Building" from Paul Bierman (1992).

2. Collecting data about housing conditions in "Kampung Sepoloh", RT. 10 RW.5 Morokrembangan, Surabaya, Indonesia.

3. Identifying the settlements in "Kampung Sepoloh", Surabaya based on the concept of "Sustainable Housing for Sustainable Cities" from UN-Habitat (2012) and "Healthy Building" from Paul Bierman-Lytle, AIA (1992).

\section{Study Area}

"Kampung Sepoloh" is one of many informal settlements in Surabaya. It is located on the street of Gresik Gadukan RT 10 RW 5 Morokrembangan. "Kampung Sepoloh" has already received many environmental awards, and recently achieve an award at the Surabaya Green and Clean competition as Best of the Best of advanced category, hosted by the Government of Surabaya. This kampung consists of 75 houses with 125 heads of family. 


\section{RESULTS AND DISCUSSION}

The following discussion is about the identification of "Kampung Sepoloh" conditions based on the concept of sustainable housing, as seen from four main dimensions (environmental, social, cultural and economic) of sustainable housing.

\section{Environmental Dimension of the Kampung}

There are some stages that considering the whole residential buildings in Kampung Sepoloh by the community, those are :

a. Planning stage: "Kampung Sepoloh" area was originally a warehouse of food, and there are only few settlements that belong to few people.

b. Building design and construction: Some warehouses were sold and built into the citizens houses.

c. Operation: Many newcomers caused dense of residential areas and made slum conditions over time. It can be seen on the amount of houses on the Bozem riverbank.

d. Refurbishment : Some houses on Bozem riverbank were evicted. The reason is settlement density, slum condition, and the area would be constructed as streets.

e. Operation: After several years, the condition of the kampung has not much improved. The Surabaya government planned to evict the kampung and allocated the area to be a green open space.

f. Refurbishment : Some people began to make efforts to improve the quality of the kampung through environmental approach, so that their home would not be evicted.

g. End of life: The kampung is not evicted - otherwise, it is become to a model kampung with environmental and achievement

The occupation of most residents in "Kampung Sepoloh" is entrepreneur. Their work area is also not far from the surrounding kampungs. There are adequate available facilities, such as prayer facilities, health (Posyandu and the elderly), public space, security, and green space with creating some parks in "Kampung Sepoloh". Those parks consist of women gardens, bozem garden, reflections garden, and harvesting garden. In addition, each household has greeneries in front of their house. These are the form of combining the compact-green concept to built environments in the kampung.

In this discussion related to the environmental performance of the building, we take two cases to look at the environmental performance on the buildings. The first case is the house of Mrs. Fa (60 years). Her house is inhabited by her, husband, and her son. Her house is considered as a good one, which has 2-storey, good materials, and the condition is neat and clean. The second house of Mrs. Si (6o years), is inhabited by her with two daughters. Viewed from the physical condition, 
her house is simpler than Mrs.Fa's which consists of only one floor, and so that the materials. Here are the identification of environmental materials performances observed on the two cases.
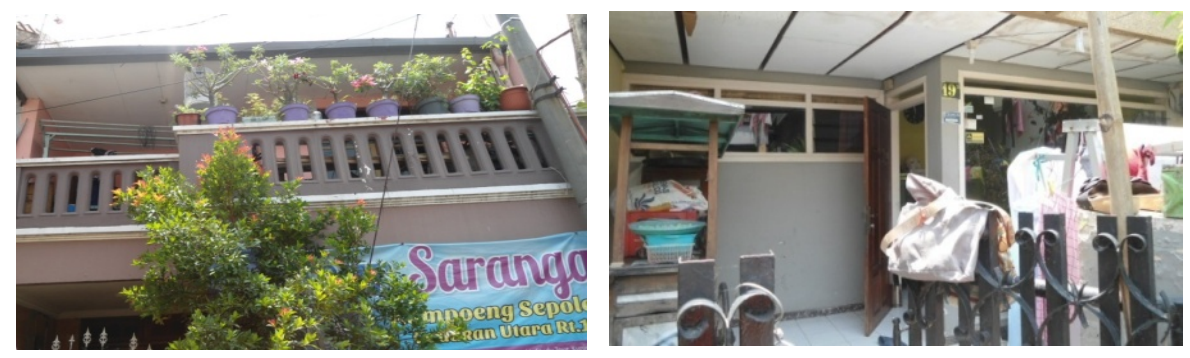

Figure 1. Case 1: Mrs.Fa's House (left) and Case 2 : Mrs.Si's House (right) Source : Author's Document

Related to sustainable building material and practices, in Case 1, Mrs. Fa and her husband built their house with inviting craftsmans. The house is built according to their financial capability, using local materials and also affordable in price, with good quality. All the house development costs obtained from their savings. As in the case of Mrs. Fa, Case 2, Mrs.Si and her husband build her house with inviting craftsman. Her house is built according to the financial capability, using affordable local materials. Related to the fees that are used to build house, Mrs.Si obtained it by borrowing money to her family, with annual installments payment. Mrs.Si's house payments is done for approximately 3-4 years, and the completion of the house took 2 years.

According to characteristic of integrating housing into sustainable community infrastructure, efforts of waste treatment have been made by the residents in "Kampung Sepoloh",such as (Figure 2) :

a. There is waste treatment effort by sorting between organic and non-organic waste. The organic is processed becoming compost collected into blue drum. This fertilizer will be used as for plants in "Kampong Sepoloh". The fertilizer is also useful to save the cost of the plants treatment.

b. The processing of eceng gondok (water hyacinth) plants growing in the Bozem water. The plant is then chopped and stored into the blue drum to be used as organic / compost fertilizer.

c. The processing of household waste through the IPAL installation (Wastewater Treatment Plant), which can be used for various needs. (Figure 2 shows the IPAL installation in the kampung).

d. The processing of non-organic or plastic waste into beautiful crafts and have a sale value. Example: Some plastic household wastes is utilized by Mrs. Fa for producing handicraft flowers, while Mrs. Si utilizes the waste to be a drinks container handicraft. 


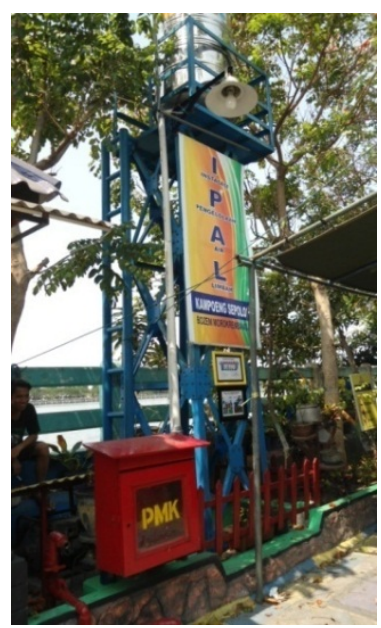

Figure 2. Waste Water Treatment in Kampung Sepoloh Source: Author's Document

In Implementing the concept of "Healthy Building" (Bierman, 1992), every house in Kampung Sepoloh is not tied to any particular cultural or architectural style. Residents make the house according to the needs, abilities and tastes of each. There is an effort to apply the concept of healthy buildings, visible from maximized greeneries in every house. However, efforts to provide air circulation and lighting in the home is still minimum due to limited land and houses density. Seen as a whole and specifically in some houses, building system in the kampung has been adapted to the health and comfort of occupants in a very simple way.

a. Cooling systems in homes is vary, either by active system with air conditioner, or by passive one. Opening forms (vents, doors, and windows) are also limited .

b. Air purification efforts Kampung Sepoloh is pursued by the habits to lead vehicle in the streets of the kampung, and to increase the greenery in front of the residents house.

c. Distribution systems and wastewater treatment in Kampung Sepoloh supported by IPAL (Wastewater Treatment Plant) facilities is adequate. Waste from households is processed at the IPAL, and the processed products was distributed back to residents. This water treatment plant is also the form of cost savings in Kampung Sepoloh plants maintenance.

d. Security and safety systems are available in Kampung Sepoloh. The security facilities includes poskamling (guardhouse), gazebo, road portals, and a home fence. There is also a simple fire extinguishing installation, as a form of early anticipation.

e. As a medium of entertainment and communication in Kampung Sepoloh, the citizens use Television with own antenna, and use mobile phones for long distance communication. However, most citizens prefer to interact with surrounding people. In addition, there are also annual events as another form of 
entertainment. (Figure 3 shows the interaction of some teenagers in "Kampung Sepoloh" making a conversation of their daily life)

In addition, talking about the use of building products in "Kampung Sepoloh", there are no special attention to the quality of the building elements, either the material components of the house, or the furniture. The considered aspects is just affordable issue and the use of elements that are commonly used. Furthermore, related to the awareness of home and Kampung environment, every citizen has its own way in caring their house. The residents also have the responsibility for maintaining the cleanliness of the surrounding and the whole "Kampung Sepoloh" environment.

\section{Social and Cultural Dimension of the Kampung}

In order to create affordabilty, dignity, and resilience of housing, the efforts of kampung improvement is carried out by residents independently. The kampung did not receive the help from goverment to make it beautiful, clean and comfortable. Therefore, the efforts to improve the quality of the house, not only the physical aspect (such as greeneries, waste management, and innovation of simple extinguishing installation is simple) but also non-physical aspect (such as the participation in kampung improvement activities). Speaking about the social and spatial justice in kampung found that there is no social inequalities in "Kampung Sepoloh", because most of the area is the area of informal settlements.

Participation in the kampung found that the movements begin with maintaining and protecting the environment, carried out by the leader of "Kampung Sepoloh", who make any approaches to the residents in various forms. Currently, all residents are already aware and participated in protecting and maintaining the environment in "Kampung Sepoloh". By empowering the local community could create local participation and inclusion.

In order to providing access to social infrastructure and facilities, the street lighting infrastructure uses common channels of PLN (State Electricity Company) which is connecting 11 RT (Kampung Region). But, the PLN now repealed the electricity channel, because once there is a case that a person take the line without permission, and it is dangerous because trigger a fire. While, the street infrastructure is originally made of cast concrete, and with the help from the government, the street uses paving material. The paving material is quite good, because it still can absorb water.

Long time ago, the condition of "Kampung Sepoloh" is relatively worse in terms of the environtmental quality.After the issue of eviction from the government, the Kampung's residents began to perform a movement, to avoid eviction. The residents make some efforts by improving the quality of the kampung through the environmental approach.The Kampung improvement effort is passed through a difficult process. Finally, the Kampung is not evicted. Consequently, it becomes a kampung model with its environmental quality and achievements.

In order to create adaptable housing for present and future needs, if judged from 2 objects (case $1 \&$ case 2), Mrs. Fa and Mrs. Si has lived in the kampung for a 
long time, and during their occupation, they could use their house as needed. They built their house individually (through craftsmans), according to their needs and financial capabilities. In case 1, Mrs. Fa's house is first built as a simple house that fit the needs of the moment. After 7 years the houses began gradually renovated.

\section{Economic Dimension in the Kampung}

Affordability of housing supply (in the scope of the Kampung) and efforts to improve the quality of the environment is done together, for example adding greeneries. The citizens participate independently and care for the environment, through concrete activities or donation. Supporting activities have been started yet not developed, such as the processing of plastic waste. However, related to improving the quality of drainage, the kampung is supported by the government through the provision of a more modern IPAL installations, as a form of waste treatment and water efficiency.

Ensuring balanced housing markets through affordable tenure choices . If viewed from the scope of the Kampung, the land tenure is vary, some are contracting, and the rest has their own ownership. The acquisition of land is also diverse, some are purchased privately from the previous land owners, the others are inherited from parents. It is clear that what is traded is land plots, then the citizens build their home according capability. If viewed from the scope of the two cases. Mrs. Si didn't dare enough to take the mortgage loan because her husband does not keep a job, so she built her house only by her own financial capabilities. While, Mrs. $\mathrm{Fa}$ is initially contracted house for 5 years. When she had sufficient funds, he bought land and started building a house on her own (with the help of carpenters).

Recognising affordable housing building as a source of employment. If viewed from the scope of the house. In the process of houses construction, people built house personally, with their own funds. The construction activities are carried out with the aid of home carpenters from outside (hiring informal workers who came from the area around the Kampung). The purchase of materials and techniques to build houses handed over to the builders, but the homeowners are able to oversee the construction work regularly. Nevertheless, the determination of the quality of building materials and techniques, depends on citizens affordability. If viewed from the scope of the Kampung. The Improvement of Kampung quality is done by every citizen. (participating and caring awareness to kampung environment) The efforts are made to minimize kampung maintenance costs, such as the manufacture of parks, greeneries, and the cleanliness of the streets.

Recognising home-based enterprises. Some residents use their dwelling as a workplace for trade. Mostly in the form of a simple business, selling basic daily needs. Small businesses are conducted by its own citizens, and in this case it is very important to generate income and provide employment. If viewed from the scope of case 1 - House of Mrs. Fa. At first, this house was used as sewing business workplace. But now, Mrs. Fa uses her house front room into a small shop. Her revenues from the store is just around Rp. 20,000.00 per day, or Rp. $600.000,00$ per month. Her small business doesn't bring significant results because of the intense 
competition with supermarkets in various places. Mrs. Fa's small businesses is used for filling activity and as an additional source of income although in small quantities. (Figure 4 show Mrs. Fa's small bussiness in front of her house). If viewed from the undeveloped potentials, plastic waste is collected in waste banks can be utilized as a useful object with sale value (handicrafts). There have been local products made by residents, in the form of food and syrup of starfruit. Unfortunately, both types of local products has not been given special attention and formally coordinated, so the potential is not well developed yet. (Figure 5 shows the product of non-organic waste made by the residents in the Kampung).

Mobilising savings and domestic finance. In order to do repairment and improvement of the Kampung quality, citizens use the local funds (kas RT) gathered from Kampung activities, competition funds, or the sale of plastic waste in the waste Bank. Various activities of the men, women, or teenagers. For example in the form of regular meetings or neighborhood meetings, lectures, activities of the PKK, etc, there is usually a voluntary fund to accommodate representatives of the people who come. When there are special events, for example: independence day celebration, the cost of the competition, performing arts, and the procurement of the prize are gathered from each family (there are 125 families), which are charged Rp.50.000,00. On the other hand, each family contributes for about Rp.7.000,00 per months to pay the garbage collectors who come to the kampung, and there are also plan operational costs collecting for street lighting in the Kampung.

\section{CONCLUSION}

"Kampung Sepoloh" has already had some achievement in sustainable housing concept, considered from the four dimensions (environmental, social, economic, and cultural). However, there are some aspects that have not run optimally. Therefore, it needs a better and innovative handling and development in every dimension, such as:

1. Environment. In terms of water efficiency, the Kampung still needs technological innovation related to water treatment in order to cover more needs.In terms of energy efficiency, each citizen needs to raise awareness of energy use to a minimum. There should be any efforts of every citizen to use more efficient and energy-saving appliances. In addition, every citizen can not abuse the source of available electrical energy because it can trigger fire.In terms of the application of the "Healthy building" concept, most people are already aware and care for their surrounding environment. Yet, every citizen also must consider the condition of the house they occupy. Due to the people lack of knowledge, the role of government is needed to hold a healthy occupancy-related counseling, which informs the importance of material use and of harmless elements.

2. Social and Cultural. Citizens are already participated in improving the quality of their surrounding environment, and it is needed to be maintained and improved, so that the achievement of kampung quality and awards will not decrease and continue increasing over time. 
3. Economics. It needs to develop the kampung potential related to the processing of non-organic waste to be used as a craft or a local product with sale value. The Kampung is already has a potential but has not been given special attention and formally coordinated.

\section{REFERENCES}

Paul Bierman-Lytle, AIA (1992), "Healthy Building: Low Toxic Construction Systems, Products and Approaches" on Sustainable Cities, Bob Walter et.al (editors).Eco-Home media, LA, California USA.

Priemus, Hugo, (2005). How to make housing sustainable? The Dutch experience. Environment and Planning B: Planning and Design 2005. OTB Research Institute for Housing, Urban and Mobility Studies, Delft University of Technology, JA Delft 2629, The Netherlands.

Tipple, G. (1993) 'Shelter as workplace: a review of home-based enterprises in developing countries', International Labour Review 132: 521-539.

UN-Habitat (2005) Financing Urban Shelter: Global Report on Human Settlements 2005. London: Earthscan.

UN-Habitat (2006) State of the World's Cities 2006/2007. Nairobi: United Nations Human Settlements Programme (UN-Habitat).

UN-HABITAT, (2012). Sustainable Housing for Sustainable Cities. UNON Publishing Service Section, Nairobi. 
Dianingrum, Rahmadaniyati: EVALUATION OF SUSTAINABLE HOUSING CONCEPT ON KAMPUNG SEPOLOH, AN INFORMAL SETTLEMENT IN SURABAYA, INDONESIA

This page is intentionally left blank 